\title{
From birth to colostrum: early steps leading to lamb survival
}

\author{
Raymond NowAK*, Pascal POINDRON
}

\begin{abstract}
Laboratoire de Comportements, Neurobiologie et Adaptation, UMR 6175 CNRS-INRA-Université François Rabelais-Haras Nationaux, Unité de Physiologie de la Reproduction et des Comportements, INRA, 37380 Nouzilly, France
\end{abstract}

\begin{abstract}
New-born lambs have limited energy reserves and need a rapid access to colostrum to maintain homeothermy and survive. In addition to energy, colostrum provides immunoglobulins which ensure passive systemic immunity. Therefore, getting early access to the udder is essential for the neonate. The results from the literature reviewed here highlight the importance of the birth site as the location where the mutual bonding between the mother and her young takes place. Attraction to birth fluids by the periparturient ewe leads to intense licking of the lamb. Grooming not only dries, cleans and stimulates the newborn it also facilitates bonding through learning of its individual odour. Ewes having twins should ideally stay on the birth site for at least six hours in order to establish a strong bond with both lambs and favour lambs survival. However, primiparous ewes or ewes having high levels of emotivity are more likely to exhibit poor maternal behaviour. In addition, difficult parturition and weather conditions have an indirect effect on the behaviour of the mother and are other major causes of lamb death. On the lamb's side, rapid access to the udder and early suckling are extremely important. Delayed lactation or insufficient colostrum yield may be fatal especially since suckling has strong rewarding properties in the establishment of a preference for the mother, which in turn increases lamb survival. Insufficient access to the udder in mothers leaving the birth site too soon after parturition, especially in twin-bearing ewes, could also partly account for the high incidence of loss of mother-young contact and subsequent death in such lambs. Strategies to improve neonatal survival should be aimed at maximising lamb vigour, colostrum production, and mutual mother-young bonding through adequate feeding in late pregnancy and selection on behaviour.
\end{abstract}

energy reserve / colostrums / suckling / maternal behaviour / bonding / ewe / lamb / nutrition / survival

\section{INTRODUCTION}

The successful transition of the neonate from the warm protective uterine womb to the external environment is a real challenge [1] and the behaviour of the lamb after birth, in combination with that of the mother, will deeply influence its chances of survival [2]. Neonates need to be vigorous in order to rapidly seek the udder, locate

\footnotetext{
* Corresponding author:

raymond.nowak@tours.inra.fr
}

the teat and suckle and to do so they must have well-adapted behaviour patterns immediately after birth. Early mother-young interactions are also crucial to ensure that a strong bond is established between the ewe and her neonate so that food is regularly supplied to the lamb. The primary functions of early maternal care are therefore to provide the lamb with colostrum to satisfy its metabolic needs and to protect it from aggression from the outside environment. The mother-young interactions 
that lead to successful suckling by newborn lambs are the results of complex physiological, morphological, and behavioural changes that ensure extra-uterine survival at a time when the young is entirely dependent upon its mother for the provision of food. Yet many lambs do not adapt to this huge change in their life style.

Neonatal mortality, in both intensive and extensive systems, remains a strong concern for sheep production. Mortality of $15-25 \%$ is common in farming systems world-wide. Most preweaning lamb deaths occur within the first week of life [2-4], emphasising the importance of the immediate post-partum period for lamb survival. The survival of the neonate depends on the complex interactions between rearing ability of the mother, lamb's viability, and climatic conditions around lambing [3-6]. In extensive systems, the majority of lamb deaths are attributed to two main causes: dystocia from prolonged or difficult birth, and the starvation-mismothering-exposure complex. Lamb deaths attributed to the starvation-mismothering-exposure complex have contributing factors such as adverse weather conditions, inadequate energy reserves, thermoregulatory problems, delayed lactogenesis, insufficient colostrum yield, aberrant maternal or lamb behaviour, competition with siblings or udder defects. This review will focus on the physiological and the behavioural factors at play during the first hours of mother-young interactions that take place on or near the birth site. The birth site is an area of a few square metres where the ewe stays to give birth and provide maternal care, and where the newborn has to find the udder to ingest vital colostrum. There the ewe must spend several hours with her $\operatorname{lamb}(\mathrm{s})$ so that the intimate mother-young interactions help develop strong mutual bonding. Independently of climatic and other environmental conditions, there are three main types of factors that may influence lamb survival at this time: the state of physiological adaptation of the lamb and the ewe at the time of parturition, the quality of the care the mother will dispense to the neonate and the behaviour of the neonate itself.

\section{NEONATAL AND MATERNAL PHYSIOLOGICAL ADAPTATION: GETTING SET FOR THE QUEST FOR COLOSTRUM}

\subsection{Energy reserves of the neonate and environmental conditions}

The first few hours after birth are critical for the survival of the newborn lamb since it must counteract the massive heat loss incurred from its transition from the warm uterine environment to the external world. During the first 15 min after birth, the internal temperature of a lamb decreases by 1 to $2{ }^{\circ} \mathrm{C}$ below the intra-uterine environment of $39{ }^{\circ} \mathrm{C}$. Lambs must increase their heat production by up to 15 times the prenatal level to compensate for this heat loss [7]. The cooler the external environment, the faster this metabolism must be to maintain homeothermy and the rate of heat loss is heightened by wind velocity, humidity and the amniotic fluids evaporating from the birth coat. To maintain homeothermy before any colostrum is ingested, the newborn must metabolise its brown fat energy reserves and increase muscular activity by shivering $[8,9]$. Brown fat provides the major source of energy but constitutes only $2-4.5 \%$ of the body weight of the lamb. Large neonates have more available lipid per kilogram of body weight than small ones. Fat reserves are disproportionately low in small lambs and in lambs being born from ewes that had been undernourished during pregnancy [10], hence giving them even less chance to survive.

The amount of energy reserves is therefore the first critical condition for survival, 
especially when weather conditions are unfavourable. If energy reserves directly influence the length of time the lamb can survive without any colostrum intake, it is the available carbohydrate, not fat, that is the main factor limiting the length of time that a newborn can resist inclement weather. The high mortality rate observed during or shortly after periods of bad weather are largely the results of hypoglycaemia which in turn produces hypothermia and death, before total depletion of the fat body reserves [4]. The combination of wind and rain, as well as low temperatures, are well documented predisposing conditions that cause lamb mortality [11-14]. Wind speed alone has also been highlighted as a very important factor increasing heat loss and lamb mortality [15]. Heat loss depends mainly on surface area while heat production is linked to body weight [9]. Hence small lambs are more predisposed to exposure and hypothermia than large lambs, because the former have a higher surface area to volume ratio and higher rate of heat loss per unit of body weight [16].

\subsection{Colostrum}

Colostrum is produced just before parturition and contains dense nutrients as well as high levels of immunoglobulin, enzymes, hormones, growth factors and neuroendocrine peptides. Because colostrum is the unique source of food for the neonate, insufficient intake is the second major factor (after body reserve) that affects neonatal survival. Colostrum contains approximately $7 \%$ fat, $4 \%$ casein, $5 \%$ lactose and $82 \%$ water $[17,18]$ and provides approximately 2 Kcal of energy per $\mathrm{mL}[19,20]$. It is estimated that 180 $290 \mathrm{~mL} \cdot \mathrm{kg}^{-1}$ body weight are required by the lamb in the first $18 \mathrm{~h}$ after birth [1] but not all mothers can fully cover their infant's need.
The amount of colostrum accumulated in the udder before parturition and the production of milk afterwards depends on the size of the litter. Twin-bearing ewes generally yield more colostrum than singlebearing ewes, but the onset of lactation is slower in the former and they do not produce as much colostrum per lamb [21-23]. This has serious implications for twins since they are often already disadvantaged by lower birth weights and lower energy reserves than singles. Therefore, inadequate supplies of colostrum diminish even more their chance of survival. In the study by McNeill et al. [22], 30\% twin-bearing ewes were estimated to have insufficient colostrum available for their lambs after birth. In addition, about $10 \%$ of the singlebearing ewes also produced insufficient colostrum for their lamb. Good nutrition of the ewe is essential to ensure that an adequate supply of colostrum is available to the lamb and that subsequent milk production rates are sufficient to cover the needs of the growing lamb [24-26].

A further function of colostrum is to transfer antibodies from the mother to the young before its own immunological protection becomes fully functional [17]. For species having an epitheliochorial placental, such as sheep, the process of transfer of immunoglobulins from the mother's colostrum is of paramount importance to neonatal survival, since the immunoglobulins do not cross the placental barrier. Once suckling is achieved, the serum immunoglobulins rise rapidly during the first hour and peak about $24 \mathrm{~h}$ after birth [20]. Immunoglobulin levels in the blood are directly related to the production of colostrum, since larger volumes of colostrum are associated with larger amounts of immunoglobulins [27, 28]. This process of passive immunoglobulin absorption in the intestine ceases at about $24 \mathrm{~h}$ of age and is referred to as intestinal closure. Therefore any delay in suckling by the lamb, due to low colostrum 
yield or to poor teat-seeking activity, reduces its chances of obtaining sufficient immunoglobulins to be protected from infection by pathogens [29].

\subsection{Birth weight, litter size, and suckling drive}

Most deaths of lambs are invariably concentrated in the first days after birth [3, 30] and are typically associated with birth weight by a curvilinear relationship. Lambs with either very high or very low birth weight are more at risk than lambs having intermediate birth weights and the optimum birth weight ranges between 3 and $5.5 \mathrm{~kg}[4,9]$. Mortality rate in twins is generally 1.5-3.0 times that of singles. Birth difficulties and dystocia are the main causes of death of large, single-born lambs. By contrast, lambs with low birth weight are predisposed to death from starvation and exposure, due to their lower energy reserves, weakness, immaturity and an abnormally high birth coat/birth weight ratio.

Mortality rates in singles and twins in the same birth range are usually similar [31]. However, in Merino sheep, mortality of twins can be above that of singles of the same weight, suggesting that factors other than birth weight may be involved [32]. Deficient maternal care in Merino ewes, especially those bearing multiples, is mainly attributed to their poor ability to maintain contact with both of their twin lambs [33]. Disparity in the vigour of twin lambs may also be a cause of lamb deaths from desertion by Merino ewes, since weak vigour may lead to uneven bonding and the death of one, or both lambs. Over $40 \%$ of twin lambs that were abandoned and perished in the study by Steven et al. [32] were the weakest of the pair. Inadequate teat-seeking activity in weak lambs is also likely to exacerbate this phenomenon, since rapid reward of initial suckling is an important factor to sustain suckling drive in young lambs. Small lambs often have a lower suckling drive than lambs of heavier weight and this is a combined effect of low birth weight, low energy reserve and general lamb weakness. Neonates that take longer to stand up and to suckle have reduced chance of survival since the suckling drive and the chances of ever suckling successfully are reduced considerably if they have not ingested any colostrum in the first six hours of birth [34-36].

\section{BEING BORN TO A CARING MOTHER}

\subsection{Seeking isolation and selecting a birth site}

The early development and survival of the newborn lamb depend entirely on the care provided by its mother. In sheep, which are gregarious, this begins with a tendency of ewes to separate themselves from the flock as parturition approaches. Even under intensive management, prelambing ewes choose to isolate themselves if they are given the opportunity by providing cubicles in the shed [37, 38]. Under extensive conditions, however, it is not always clear whether parturient ewes actively seek isolation [39] or are left behind by the flock [40]. Nonetheless in all instances, there is a reduction of gregariousness of ewes around lambing which is not due to the bonding process with the neonate, since it already exists prior to lambing [41]. This shift in social motivation optimises the establishment of satisfactory mother-offspring relationships, while minimising the risk of interference by other pre-parturient ewes. Indeed, disturbances in the establishment of the mother-young relationship are common among ewes lambing in the presence of other parturient females [33, 42]. Twenty percent of pre-parturient Merino ewes may 
be attracted to lambs of other ewes and interest ranges from brief inspection, grooming, suckling and even stealing of the newborn [43]. Unfortunately, the alien is often abandoned when the ewe delivers her own lamb.

Seeking shelter may contribute further to isolation from the flock. However domestic preparturient ewes usually only seek shelter in cold, windy and wet weather. Again, this appears to vary according to the breed [44]. In general, adult Merino sheep with a full fleece make little use of shelter unless wind speed is over $40 \mathrm{~km} \cdot \mathrm{h}^{-1}$, however, prelambing shearing may increase sheltering [45]. In contrast Lacaune ewes, which do not have a thick fleece, choose to give birth in shrubby sites when the wind speed is over $10 \mathrm{~km} \cdot \mathrm{h}^{-1}$, even if there is no rain [39]. Shelter is not the only parameter females may use to select a birth site, even though the clues that ewes rely on are not necessarily obvious. Some studies indicate that the distribution of birth sites is not random, and Merino ewes seem to prefer the high end of the paddock as lambing areas [44]. In most instances, the exact site of birth is determined by the place where the foetal fluids are first spilled [43].

\subsection{Grooming the lamb}

Grooming of the lamb by the ewe during the first postpartum hours depends on the attraction for the foetal fluids. Maternal licking not only dries, cleans and stimulates the lamb, it also entrains additional maternal care and facilitates the formation of a strong bond with the newborn lamb through recognition of its odour [46]. It may be delayed in primiparous ewes or those that have experienced difficult births [43,46,47]. With multiple births, the ewe seems to lose interest in the first-born lamb when the second lamb is born. Despite this shift of attention, second-born lambs do not receive as much grooming as first-born twins [48-50]. Because ewes take longer to lick multiple-born lambs dry, these are predisposed to hypothermia in adverse conditions. While grooming, the dam emits frequent low-pitched bleats or rumbling noises with the mouth closed, and occasional high-pitched openmouth bleats [51,52]. Low-pitched maternal bleats are emitted almost exclusively in the presence of the lamb and like licking, decline over time. These are thought to quieten the newborn and to provide cues for later recognition of the dam. In contrast, the rate of high-pitched bleats increases with time and they are used for distal communication

\subsection{Getting bonded to the whole litter}

Ewes remain attracted to the birth site for several hours after parturition and this is generally where the mother-young relationship is formed. Under optimal conditions, ewes rapidly develop a selective bond with their newborn lamb(s). The primary developmental mechanism implicated in the establishment of the motheryoung bond is a rapid learning of the lamb's distinctive phenotypic "olfactory signature" $[53,54]$. Immediately after parturition ewes respond maternally to alien young as well as their own. Recent studies have demonstrated that 30-60 min of immediate post-partum contact with a neonate may be sufficient for the ewe to become familiar with that lamb's unique signature and discriminate her lamb from alien ones [55]. Once established, this maternal bond is characterised by the exclusive nursing of the ewe's own lamb, along with the rejection of all alien young that approach her udder.

The first hours postpartum therefore represent a critical time for the establishment of the maternal bond towards her young (reviewed in [56]). Under extensive 
conditions, abnormal behaviour or external disturbances at this stage can lead to separation and death of young, especially in ewes giving birth to twins. In Merinos, the incidence of permanent separations of ewes and lambs range from 25 to $50 \%$ [32, 33 ] and a further $30 \%$ of twin-bearing ewes may become temporarily separated from one of their twins in the first few days after parturition. The ewes separated from part of their litter appear satisfied that one lamb only is following. By contrast, crossbred Border Leicester ewes separate from their twin lamb less frequently than purebred Merino [13]. However, the role of the lamb's behaviour in these separations from the mother is probably of some importance even though it is not fully understood [57, 58]. Proper establishment of a bond depends on the time spent on the birth site or nearby. Poorly bonded mother-young units that leave the birth site too soon after parturition have higher incidence of separations and higher mortality [24, 33, 59]. Ideally, ewes should remain on their birth site for at least six hours after parturition with the whole litter in order to attach strongly to all the lambs and optimise their chance of survival. However, this is rarely the case for Merino ewes. Most ewes leave the birth site rapidly to find food and water and their move can be hastened by disturbances caused by humans, dogs or nervousness [60]. Hunger caused by sparse pasture cover and poor ewe conditions at parturition can motivate them to leave the birth site [61] and increase the probability of interference from other parturient ewes. In addition, the inherent temperament of the Merino and their strong gregariousness may cause them to move away from the birth site too soon after parturition, well before strong ewe-lamb attachments have been fully formed.

Even when the various elements and cues that normally contribute to the onset of maternal behaviour are optimal, primiparous ewes are often less competent than experienced ewes, and the mortality of their lambs is higher. Primiparous ewes tend to have longer labour than multiparous ewes and are slower to begin grooming their lambs [50]. They are also more likely to show fearful behaviour towards the lamb, they may be more aggressive and in some cases they may fail to show maternal behaviour and abandon their lamb. In inexperienced mothers, the newborn may be seen as a novel and potentially fearful stimulus leading to initial disturbances in up to $50 \%$ of mothers in some instances [54], with more than $20 \%$ of primiparous ewes still failing to nurse their young after three hours. However, after mothers have gained maternal experience at their first lambing, they show improved maternal care in their subsequent pregnancies [62].

\section{SUCKLING AND GETTING ATTACHED TO THE MOTHER}

\subsection{Finding the teat}

Because lambs are born with little energy reserves, it is vital that they find the teat and ingest colostrum as soon as possible. The expulsion process results in an intense physiological and behavioural stimulation of the neonate [63]. This sustained arousal promotes exploration of the mother's body and perception of sensory cues which will guide the neonate towards the udder. They find the udder by exploring the underneath of the ewe's body from the chest to the udder. In particular they spend time nosing the axillary and inguinal areas of the udder until the teat is found. Thermotactile cues play a crucial role in the search for the teat since lambs make munching movement once they come into contact with the mother's body [64] Lambs also respond to the smell of amniotic fluids and inguinal wax with head movements, oral activity, exploration, and 
increased breathing and heart rates $[65,66]$. Most lambs begin to suckle within the first two hours of delivery, however, significant differences between breeds in the early behaviour of lambs have been reported [51, 67-69]. Birth weight, gender and litter size may also influence the time lambs take to stand and find the teat. Male lambs are usually slower than females in the expression of early behaviour and twins slower than singletons, although some authors suggest that this twin effect is a function of reduced birth weight.

\subsection{Getting attached to the mother}

Ewes move away from their birth site within hours after parturition. Since neonates need to suckle hourly, following the mother is their best survival strategy in order to keep in the vicinity of the source of colostrum. In addition, once the mother and her litter have joined the flock of ewes many of which are lactating, the mother will remain the only source of food, due to the existence of exclusive nursing. It is therefore highly beneficial to the lamb to get rapidly attached to its dam. Most lambs can discriminate between their mother and an alien maternal ewe 12 to $24 \mathrm{~h}$ after birth $[70,71]$ and this ability still improves markedly during the first few days postpartum [72]. While recognition of the mother at $24 \mathrm{~h}$ is based primarily on cues that lambs can perceive at close quarters, they can clearly discriminate their mother from a distance of several metres when 3 days old [73]. The development of early recognition of the dam varies according to breed, sex, and litter size $[71,72]$. Twins commonly take more than two days before they begin to show a preference for their dam. Even then, behavioural differences still persist between singles and twins [73].

The development of a preference for the mother by 24 -h old lambs depends mainly on their first successful suckling bouts.
When suckling is prevented during the first few hours after birth, the lambs' discriminative ability is impaired by 24 to $48 \mathrm{~h}$, an effect that cannot be attributed to overall reduction of colostrum intake $[74,75]$. The longer neonatal suckling is prevented, the longer the preference for the mother takes to develop [76]. These effects are unique to the neonatal period since they are not observed when suckling is temporarily prevented later in life. That is, preventing a three-day-old lamb from accessing the udder for a few hours does not affect the preferential relationship that had already been established between the dam and offspring as measured $24 \mathrm{~h}$ later [74]. In a related study Napolitano et al. [77] have shown that lambs that are permitted to suckle only during the first day after birth and then remain with their dam without being allowed to suckle, still display a strong preference for her at one month of age.

Ingestion of colostrum plays a key role in this rewarding process $[75,78,79]$. Both ovine or bovine colostrum, collected within hours after parturition, were as efficient, while ewe milk obtained at three weeks of lactation was less effective [79]. Non nutritive liquids ingested in equivalent small amounts (2.5\% to 5\% birth body weight) did not facilitate the establishment of a preference for the mother [75, 79]. Even an isocaloric solution of lactose, the main sugar found in colostrum, was not followed by any specific behavioural output, suggesting that energy intake per se is not the primary factor controlling the development of this early filial bonding. However, when lambs ingested larger amounts of fluids (up to $10 \%$ birth body weight), the development of a preference for the mother was facilitated both by colostrum and non nutritive fluids. Therefore, beyond a threshold, the volume of ingesta can also facilitate early filial bonding independently from any caloric or nutritional input [75]. Thus, ingesting colostrum is not just a way of getting 
nutrients and energy supply for the lamb. Through the cascade of neurophysiological events that are triggered during suckling, colostrum ingestion also shapes the behaviour of the neonate with biochemical and visceral mechanical stimulation. Recent studies have also demonstrated that non nutritive sucking facilitated early filial bonding [80].

\section{STRATEGIES TO IMPROVE NEONATAL SURVIVAL}

The interactions taking place between the ewe and her litter during the first postpartum hours are vital for the establishment of mutual bonding. This in turn represents an excellent "life insurance" for the lamb and a primary key of the reproductive success of the ewe. While this mutual bonding usually develops without difficulties, there are still possibilities to improve it (e.g. primiparous or nervous mothers, twin-bearing ewes), and hence increase lamb survival.

\subsection{Acting on the mother}

\subsubsection{Management at parturition}

Various aspects of ewe behaviour may contribute directly or indirectly to the incidence of lamb mortality. Good shelter- and isolation-seeking behaviour by the preparturitent ewe can increase lamb survival. In studies with Merino ewes, provision of shelter reduced lamb mortality in poor weather by up to $50 \%[13,14,81]$. Even in intensive systems, parturient ewes offered access to cubicles in lambing sheds showed a marked preference to lamb in the cubicles rather than in open pens [38]. This resulted in a reduction of ewe-lamb separation and lamb stealing by preparturient ewes, compared to control pens without cubicles [37].

Time spent at the birth site has also been shown to correlate with lamb survival in
Merino ewes [32, 33, 59, 82]. Characteristics of the birth site per se appear to be less important than the ewe remaining undisturbed with her lambs for at least $6 \mathrm{~h}$ [24]. Thus, isolation from the flock at parturition facilitates formation of the ewe-lamb bond without interference from other ewes, and appears to be an important ewe trait for the survival of the lamb. Management practices where ewes and lambs are moved too early from the birth site may disrupt the normal transfer of maternal attention from the birth site to the lamb and hinder the formation of the ewe-lamb bond. This is likely to be particularly detrimental to primiparous mothers or nervous ewes in general which are more easily disturbed by external disturbances than experienced and calm ewes (primipara: [54], nervous mothers: [83]). Fear, stress or disturbance is known to cause involuntary suppression of uterine contractions in mammals during labour. For ewes unaccustomed to human presence, close supervision may act as a source of stress and unnecessarily delay or prolong parturition. Thus a low stress environment for lambing ewes is likely to be associated with better welfare for the ewe, and improved lamb survival.

\subsubsection{Nutrition during pregnancy}

Ewes that are under-fed during pregnancy give birth to low birth weight lambs with heightened mortality rates. Additional adverse effects of maternal undernutrition include reduced udder development as well as colostrum production and quality (see Banchero et al., pp. 447-461). Nutritional supplementation during mid or late pregnancy can be used to reduce lamb mortality by increasing the birth weight of the lamb $[84,85]$, increasing colostrum and milk production [26, 86, 87]. Indeed, ewes that are underfed during pregnancy have differing physiological profiles during gestation compared to well-fed ewes. 
Low nutrition is associated with higher plasma progesterone in late gestation [88], and a lower ratio of oestradiol to progesterone at birth [89]. High plasma progesterone is negatively related to colostrum and milk yield and therefore may threaten the survival of newborn lambs. In addition, progesterone and oestradiol are involved in the onset of maternal behaviour, and high ratios of oestradiol to progesterone are correlated with maternal grooming behaviour [90]. Therefore nutrition of the ewe during gestation and at parturition can also influence her maternal behaviour. Elevated progesterone in underfed ewes might contribute to poor maternal behaviour. Under-fed ewes actually take longer to interact with their lambs [91], display more aggression, spend less time grooming and more time eating after birth [89], and are more likely to desert their lambs [61].

\subsubsection{Individual differences and breed differences}

Ewes may differ in the maternal care they express, e.g. the amount of grooming behaviour, responses to the lamb's suckling attempts, likelihood of desertion. These differences usually persist over successive births [62] suggesting that they are intrinsic to the individual. One of the most frequently explored sources of maternal behaviour variation is breed differences. Many breeds have been compared, and different behavioural measures recorded. The chosen breeds generally reflect the prevalent or commercially important races in the countries where they have been studied: for example, behavioural comparisons between the Merino, Perendale, Romney, Border Leicester, Cheviot, Dorset Horn and crossbreds in Australia and New Zealand [92], between Romanov, Lacaune, Préalpes du Sud, and Île-deFrance in France $[47,93]$ and between Dalesbred, Scottish Blackface, Suffolk and
Soay breeds in the UK [62]. Because these studies used a variety of behavioural measures that differed between studies, it is hard to draw any clear conclusions, except when comparing breeds within the same study.

Nonetheless, observations in Australia and New Zealand suggest that Merinos are generally poorer mothers than other breeds: as mentioned above they spend less time on the birth site, and have a much higher incidence of both permanent and temporary desertions of their lambs than other breeds [94]. When ewes' responses to handling of their lamb were scored, Merino ewes also rated lower than other breeds [92]. In French and British breeds, Romanov and Scottish Blackface ewes are considered to show better maternal care (more licking, grooming and lamb acceptance; less aggression) than the other breeds $[47,93]$. Thus it is clear that considerable breed differences exist in the quality of expressed maternal behaviour. In general, hill, upland and harsher breeds, which have been subjected to less human intervention, show better quality of maternal care, whereas more intensively selected and reared animals display greater variability in maternal behaviour and make the poorest mothers.

\subsubsection{Selecting for better mothers}

Attempts to select for better mothers have been carried out following various criteria. For example, in flocks selected to improve lamb survival to weaning, the main outcome of the selection process is an increase in the speed and ease of parturition [95], swift parturition clearly emerging as an important parameter for lamb survival. As a matter of fact, prolonged labour can increase the possibility of brain trauma and hypoxia in the neonate [96] and therefore impair suckling, locomotor activity and thermoregulation [20, 97, 98]. 
Similar responses are seen in 'easy-care' Romney ewes [99].

Maternal behaviour has also been assessed using a composite measure of ewes' reactions when their lambs are handled by a shepherd [100]. This score shows variation within and between breeds [92, $100]$ and is related to both lamb survival and weaning weight. Heritability estimates of this measure for Scottish Blackface ewes [101] are relatively low but there was good reliability.

The consistency displayed by individuals may reflect their underlying emotivity or "temperament", which may or may not influence maternal behaviour per se. Romanov ewes, for example, are considered to be better mothers (in terms of licking, grooming and attachment to the lamb) in comparison to the Lacaune breed [93]. Yet, Romanov ewes display greater flight from humans and stand further from their handled lambs than Lacaunes, a behaviour that would have earned them a lower maternal behaviour score in the studies by Whateley et al. [92] and O'Connor et al. [100]. These responses are believed to result from greater emotivity of the Romanov breed rather than a poorer quality of maternal care. In contrast, in studies where Merino ewes were selected for temperament by measuring their responses to a variety of tests, the 'calm' ewes spent more time grooming their lambs than did 'nervous' ewes, and bleated more frequently to their lambs [83]. Lamb mortality in these lines was also lower in the 'calm' ewes compared to the 'nervous' animals. Ewes previously selected for their ability to rear lambs also show behavioural differences in an approach avoidance test, indicative of increased 'calmness' [102]. Thus, temperament may also contribute to individual differences in the quality of maternal care expressed by ewes.

Within-breed studies indicate that ewe maternal behaviour may be affected by genotype even when that characteristic had not been included in the selection criteria [103-105]. For example, Merino ewes selected for superfine wool were less maternally responsive and had higher lamb mortality than broader wool Merinos [103]. Blackface ewes selected for low carcass fat were quicker to groom their newborn and stayed closer to it immediately after delivery than ewes selected for more carcass fat [104]. In other studies where improved maternal ability was the aim, lamb survival was greater for Merino ewes selected for fertility and success in rearing multiple offspring, than for unselected or divergently selected lines $[95$, 106]. This selection criterion decreased desertion of lambs, although the main effect appeared to be an improvement in parturition, such as ease and speed of delivery. The 'easy-care' Romney sheep produced in New Zealand show a similar ability to give birth unaided [107]. These data suggest that some aspects of maternal behaviour are under genetic control, although few estimates of genetic parameters (heritability, phenotypic and genetic correlations) exist. Similarly, in studies where Merino ewes were selected for temperament, the 'calm' ewes spent longer time grooming their lambs than did 'nervous' ewes, and bleated more frequently to their lambs [83]; mortality was also lower in the line of 'calm' ewes than in the line of 'nervous' animals. Potentially, therefore, it is possible to improve maternal care through genetic means.

\subsection{Acting on lamb behaviour}

\subsubsection{Strategic feeding for the lamb}

Lamb survival relies largely on early access to colostrum and the formation of filial bonding. Therefore optimal colostrum availability and vigour of the lamb must be achieved. This is particularly true when practices are designed to increase productivity through an increase in lambs born per 
ewe which in turn are likely to carry a cost in terms of lamb deaths (e.g. reduced birth weight, mother-young separation). Food supplementation during late pregnancy in twin-bearing ewes is certainly to be regarded as a priority. In addition to its positive impact on the mother [61] food supplementation is likely to directly improve the survival of the neonate through increased weight $[84,85,108]$, increased colostrum and milk yield $[86,87,109]$ and increased growth rate of lambs [110]. A higher production of colostrum may also improve lamb survival indirectly by facilitating early filial bonding and improving following behaviour when the ewe moves away from the birth site.

\subsubsection{Breed differences and selection}

The strain and breed differences of early behaviour and bonding ability of lambs [71, 95, 103, 104, 111, 112] suggest a breeding route to improve lamb survival. In Merino sheep divergently selected for multiple rearing ability, the high line lambs were quicker to progress from standing to sucking than the low line [95], and had improved survival. In additional studies on selection for other characteristics, e.g. lean tissue content had an unexpected positive effect in improving lamb activity at birth [104]. Since vocal activity of lambs correlates with their ability to bond to their dam [113], it may be worthy to take this parameter or related ones in selection plans. Recently, it has been found in studies where Merino ewes were selected for temperament, that when isolated from their mother the distress-like behaviour expressed by 'nervous' lambs was exacerbated compared to 'calm' lambs [114]. The meaning of this behavioural difference is unclear but it suggests that there are genetic influences on neonatal lamb behaviour, which appear to be independent of breed effects on other traits that influence behaviour. In addition, the strong effect of the sire on lamb behaviour suggests that breeding sires for improved lamb vigour is feasible. Thus appropriate selection of sire breeds or individual rams is also likely to improve lamb survival. This may be particularly effective if applied to vulnerable groups, such as first parity ewes, where breeding management for vigorous lambs is likely to have the most significant welfare benefits.

\section{CONCLUSION}

The farming strategies that will help the neonate to adapt successfully post-natally must start long before the lamb is born. Choice of breed or strain of sheep best adapted to rearing condition (e.g. "calm" sheep, easy care type of ewe for extensive conditions), but also specific management aimed at satisfying the need of multiplebearing ewes are the first steps to consider, since they all have some influence at parturition on the behaviour of both the ewe and the lamb. The second and potentially very important step is that of strategic feeding of pregnant ewes. Short term feeding in late pregnancy will ensure that maternal and lamb physiology will be optimally tuned to meet the challenge of the drastic environmental changes caused by birth. Finally, ensuring that mother and twins maintain close contact for at least six hours after parturition is a further factor of lamb survival.

\section{REFERENCES}

[1] Mellor DJ. Integration of perinatal events, pathophysiological changes and consequences for the newborn lamb. Br Vet J 1988, 144: 552-569.

[2] Nowak R, Porter RH, Levy F, Orgeur P, Schaal B. Role of mother-young interactions in the survival of offspring in domestic mammals. Rev Reprod 2000, 5: 153-163.

[3] Watson RH. Observed levels of mortality in relation to lambing and early stages of 
growth of sheep in Australia. World Rev Anim Prod 1972, 8: 104-113.

[4] Alexander G. Constraints to lamb survival. In: Lindsay DR, Pearce DT (Eds), Reproduction in sheep, Canberra: Australian Academy of Science, Australian Wool Corporation, 1984, p 199-208.

[5] Alexander G. What makes a good mother? Components and comparative aspects of maternal behaviour in ungulates. Proc Aust Soc Anim Prod 1988, 17: 25-41.

[6] Eales FA, Small J, Gilmour JS. Neonatal mortality of lambs and its causes. In: Haresign W (Ed), Sheep Production, London: Butterworths, 1983.

[7] Alexander G. Temperature regulation in the newborn lamb. V. Summit metabolism. Aust J Agric Res 1962, 13: 144-164.

[8] Alexander G, Williams D. Shivering and non-shivering thermogenesis during summit metabolism in young lambs. J Physiol (Lond) 1968, 198: 251-276.

[9] Alexander G. Birth weight of lambs: influences and consequences. In: Elliot K, Knight J (Eds), Size at birth, Amsterdam, Elsevier, 1974.

[10] Sykes AR. The shelter requirements of the newborn lamb. Proc NZ Soc Anim Prod 1982, 42: 7-11.

[11] Obst JM, Day HR. The effect of inclement weather on mortality of Merino and Corriedale lambs on Kangaroo Island. Proc Aust Soc Anim Prod 1968, 7: 239242.

[12] Obst JM, Ellis JN. Weather, ewe behaviour and lamb mortality. Agric Rec 1977, 4: 44-49.

[13] Alexander G, Lynch JJ, Mottershead BE, Donnelly JB. Reduction in lamb mortality by means of grass wind-breaks: results of a five-year study. Proc Aust Soc Anim Prod 1980, 13: 329-332.

[14] Lynch JJ, Mottershead BE, Alexander G. Sheltering behaviour and lamb mortality amongst shorn Merino ewes lambing in paddocks with restricted area of shelter or no shelter. Appl Anim Ethol 1980, 6: 163 174.

[15] Egan JK, McLaughlin JW, Thompson RL, McIntyre JS. The importance of shelter in reducing neonatal lamb deaths. Aust J Exp Agric Anim Husb 1972, 12: 470-472.

[16] Sykes AR, Griffiths RG, Slee J. Influence of breed, birth weight and weather on the body temperature of newborn lambs. Anim Prod 1976, 22: 395-402.

[17] Levieux D. Transmission de l'immunité passive colostrale : le point des connaissances. In: Jarrige R (Ed), Physiologie et Pathologie Périnatales chez les Animaux de Ferme, Paris, INRA, 1982, p 345-369.

[18] Hadjipanayiotou M. Composition of ewe, goat and cow milk and of colostrum of ewes and goats. Small Rum Res 1995, 18: 255262.

[19] McGance I, Alexander G. The onset of lactation in the Merino ewes and its modification by nutritional factors. Aust J Agric Res 1959, 10: 699-719.

[20] Eales FA, Small J. Effects of colostrum on summit metabolic rate in Scottish blackface lambs at five hours old. Res Vet Sci 1981, 30: $266-269$.

[21] Alexander G, Lloyd DH. Relationship of milk production to number of lambs born or suckled. Aust J Agric Res 1959, 10: 721724.

[22] McNeill D, Murphy PM, Purvis IW Lactogenesis and colostrum production in ewes. Proc Aust Soc Anim Prod 1988, 17: 437.

[23] Hall DG, Egan AR, Foot ZJ, Parr RA Effect of litter size on colostrum production in crossbred ewes. Proc Aust Soc Anim Prod 1990, 18: 240-243.

[24] Murphy PM, Lindsay DR, Purvis IW. The importance of the birth site on the survival of Merino lambs. Proc Aust Soc Anim Prod 1994, 20: 251-254.

[25] Hall DG, Piper LR, Egan AR, Bindon BM Lamb and milk production from Booroola ewes supplemented in late pregnancy. Aus J Exp Agric 1992, 32: 587-593.

[26] Hall DG, Holst PJ, Shutt DA. The effects of nutritional supplements in late pregnancy on ewe colostrum production, plasma progesterone and IGF-1 concentrations. Aus J Exp Agric 1992, 43: 325-337.

[27] Shubber AH, Doxey DL. Colostrum production by ewes and the amounts ingested by lambs. Res Vet Sci 1979, 27:2 80-282.

[28] Shubber AH, Doxey DL, Black WJ, FitzSimons J. Immunoglobulin levels in ewe colostrum and in lamb serum. Res Vet Sci 1979, 27: 283-285.

[29] Sawyer M, Willadsen CH, Osburn BI, McGuire TC. Passive transfer of colostral immunoglobulins from ewe to lamb and its 
influence on neonatal lamb mortality. J Am Vet Med Assoc 1977, 171: 1255-1259.

[30] Hight GK, Jury KE. Hill country sheep production. II. Lamb mortality and birth weights in Romney and Border Leicester $x$ Romney flocks. NZ J Agric Res 1970, 13: 735-752.

[31] Purser AF, Young GB. Mortality among twin and single lambs. Anim Prod 1964, 6: 321-329.

[32] Stevens D, Alexander G, Lynch JJ. Lamb mortality due to inadequate care of twins by Merino ewes. Appl Anim Ethol 1982, 8: 243-252.

[33] Alexander G, Stevens D, Kilgour R, de Langen H, Mottershead BE, Lynch JJ. Separation of ewes from twin lambs: incidence in several sheep breeds. Appl Anim Ethol 1983, 10: 301-317.

[34] Alexander G. The behaviour of newly born lambs. Proc Aust Soc Anim Prod 1958, 2: 123-125.

[35] Alexander G. Lamb survival: physiological considerations. Proc Aust Soc Anim Prod 1964, 5: 113-122.

[36] Alexander G, Williams D. Teat-seeking activity in lambs during the first hours of life. Anim Behav 1966, 14: 166-176.

[37] Gonyou HW, Stookey JM. Behavior of parturient ewes in group-lambing pens with and without cubicles. Appl Anim Behav Sci 1985, 14: 163-171.

[38] Gonyou HW, Stookey JM. Use of lambing cubicles and the behavior of ewes at parturition. J Anim Sci 1983, 56: 787-791.

[39] Lécrivain E, Janeau G. Comportement d'isolement et de recherche d'abri de brebis agnelant en plein air dans un système d'élevage à caractère extensif. Biol Behav 1987, 12: 127-148.

[40] Stevens D, Alexander G, Lynch JJ. Do Merino ewes seek isolation or shelter at lambing? Appl Anim Ethol 1981, 7: 149155.

[41] Poindron P, Soto R, Romeyer A. Decrease of response to social separation in preparturient ewes. Behav Proc 1997, 40: 45-51.

[42] Welch RA, Kilgour R. Mis-mothering among Romney. NZ J Agric 1970, 25: 771776.

[43] Arnold GW, Morgan PD. Behaviour of the ewe and lamb at lambing and its relation to lamb mortality. Appl Anim Ethol 1975, 2: $25-46$
[44] Alexander G, Stevens D, Bradley LR Distribution of field birth-sites of lambing ewes. Aust J Exp Agric 1990, 30: 759-767.

[45] Lynch JJ, Alexander G. Sheltering behaviour of lambing Merino sheep in relation to grass hedges and artificial windbreaks. Aust J Agric Res 1977, 28: 691701.

[46] Poindron P, Le Neindre P. Endocrine and sensory regulation of the maternal behavior in the ewe. Adv Study Behav 1980, 11: 75-119.

[47] Poindron P, Raksanyi I, Orgeur P, Le Neindre P. Comparaison du comportement maternel en bergerie à la parturition chez des brebis primipares ou multipares de race Romanov, Préalpes de Sud et Île-de-France. Gén Sélect Evol 1984, 16: 503-522.

[48] O'Connor CE, Lawrence AB, Wood-Gush DGM. Influence of litter size and parity on maternal behaviour at parturition on Scottish Blackface sheep. Appl Anim Behav Sci 1992, 33: 345-355.

[49] Owens JL, Bindon BM, Edey TN, Piper LR. Behaviour at parturition and lamb survival of Booroola Merino sheep. Livest Prod Sci 1985, 13: 359-372.

[50] Dwyer CM, Lawrence AB. Variability in the expression of maternal behaviour in primiparous sheep: effects of genotype and litter size. Appl Anim Behav Sci 1998, 58: 311-330.

[51] Dwyer CM, McLean KA, Deans LA, Chirnside J, Calvert SK, Lawrence AB. Vocalisations between mother and young in sheep: effects of breed and maternal experience. Appl Anim Behav Sci 1998, 58: 105-119.

[52] Shillito EE, Hoyland VJ. Observation on parturition and maternal care in Soay sheep. J Zool 1971, 165: 509-512.

[53] Lévy F, Kendrick K, Keverne EB, Porter RH, Romeyer A. Physiological, sensory and experiential factors of parental care in sheep. Adv Study Behav 1996, 25: 385473.

[54] Poindron P, Nowak R, Levy F, Porter RH, Schaal B. Development of exclusive mother-young bonding in sheep and goats. Oxf Rev Reprod Biol 1993, 15: 311-364.

[55] Keller M, Meurisse M, Poindron P, Nowak R, Shayit M, Ferreira G, Lévy F. Maternal experience influences the establishment of visual/auditory, but not of olfactory recognition of the newborn baby lamb by ewes at 
parturition. Dev Psychobiol 2003, 43: 167176.

[56] Poindron P, Keller M, Lévy F. Maternal responsiveness and maternal selectivity in domestic sheep and goats: the two facets of maternal attachment. Dev Psychobiol 2006, (in press).

[57] Stevens D, Alexander G, Mottershead BE, Lynch JJ. Role of the lambs in post-partum separation of ewes from twin lambs. Proc Aust Soc Anim Prod 1984, 15: 751.

[58] Nowak R, Lindsay DR. Discrimination of Merino ewes by their newborn lambs: important for survival? Appl Anim Behav Sci 1992, 34: 61-74.

[59] Putu IG, Poindron P, Lindsay DR. Early disturbance of Merino ewes from the birth site increases lamb separations and mortality. Proc Aust Soc Anim Prod 1988, 17: 298-301.

[60] Morgan PD, Arnold GW, Charlick AJ. The response of newly lambed ewes to handling of their lambs. J Aust Inst Agric Sci 1974, June: 149-150.

[61] Putu IG, Poindron P, Lindsay DR. A high level of nutrition during late pregnancy improves subsequent maternal behaviour of Merino ewes. Proc Aust Soc Anim Prod 1988, 17: 294-297.

[62] Dwyer CM, Lawrence AB. Maternal behaviour in domestic sheep (Ovis aries): constancy and change with maternal experience. Behaviour 2000, 137: 1391-1413.

[63] Lagercrantz H, Slotkin TA. The "stress" of being born. Sci Am 1986, 254: 100-107.

[64] Vince MA. Newborn lambs and their dams: the interaction that leads to sucking. Adv Study Behav 1993, 22: 239-268.

[65] Vince MA, Ward TM. The responsiveness of newly born Clun Forest lambs to odour sources in the ewe. Behaviour 1984, 89: 117-127.

[66] Schaal B, Orgeur P, Arnould C. Olfactory preferences in newborn lambs: Possible influences of prenatal experience. Behaviour 1995, 132: 351-365.

[67] Dwyer CM, Lawrence AB. Does the behaviour of the neonate influence the expression of maternal behaviour in sheep? Behaviour 1999, 136: 367-389.

[68] Slee J, Springbett A. Early post-natal behaviour in lambs of ten breeds. Appl Anim Behav Sci 1986, 15: 229-240.
[69] Dwyer CM, Lawrence AB, Brown HE, Simm G. Effect of ewe and lamb genotype on gestation length, lambing ease and neonatal behaviour of lambs. Reprod Fertil Dev 1996, 8: 1123-1129.

[70] Val-Laillet D, Nowak R. Socio-spatial criteria are important for the establishment of maternal preference in lambs. Appl Anim Behav Sci 2006, 96: 269-286.

[71] Nowak R, Lindsay DR. Effect of genotype and litter size on discrimination of mothers by their twelve-hour-old lambs. Behaviour 1990, 115: 1-13.

[72] Nowak R, Poindron P, Putu IG Development of mother discrimination by single and multiple newborn lambs. Dev Psychobiol 1989, 22: 833-845.

[73] Nowak R. Mother and sibling discrimination at a distance by three- to seven-day-old lambs. Dev Psychobiol 1990, 23: 285-295.

[74] Nowak R, Murphy TM, Lindsay DR, Alster P, Andersson R, Uvnas-Moberg K. Development of a preferential relationship with the mother by the newborn lamb: importance of the sucking activity. Physiol Behav 1997, 62: 681-688.

[75] Val-Laillet D, Simon M, Nowak R. A full belly and colostrum: two major determinants of filial love. Dev Psychobiol 2004, 45: 163-173.

[76] Nowak R, Boivin X. De la relation mère-jeune à la relation homme-animal: l'exemple de l'agneau. In: Baudoin C (Ed), L'Éthologie Appliquée Aujourd'hui, Vol I : Bien-Être, Élevages et Expérimentation. Paris: Editions ED, 2002, p 127-35.

[77] Napolitano F, Annicchiarico G, Caroprese M, De Rosa G, Taibi L, Sevi A. Lambs prevented from suckling their mothers display behavioral, immune and endocrine disturbances. Physiol Behav 2003, 78: 81-89.

[78] Goursaud AP, Nowak R. Colostrum mediates the development of mother preference by newborn lambs. Physiol Behav 1999, 67: 49-56.

[79] Nowak R, Goursaud AP, Orgeur P, Lévy F, Boivin X, Uvnas-Moberg K. Development of mother preference by newborn lambs: colostral factors and CCK. Physiol Behav, (submitted).

[80] Val-Laillet D, Giraud S, Tallet C, Boivin $\mathrm{X}$, Nowak R. Non nutritive sucking: one of the major determinants of filial love. Dev Psychobiol 2006, 48: 220-232. 
[81] Alexander G, Lynch JJ. Phalaris windbreaks for shorn and fleeced lambing ewes. Proc Aus Soc Anim Prod 1976, 11: 161164.

[82] Cloete SWP. Observations on litter size, parturition and maternal behaviour in relation to lamb mortality in fecund Dormer and South African Mutton Merino ewes. SA J Anim Sci 1992, 22: 214-221.

[83] Murphy PM, Lindsay DR, Le Neindre P. Temperament of Merono ewes influences maternal behaviour and survival of lambs. Proc 32nd Cong Int Soc Appl Ethol 1998, 32: 131.

[84] Lynch JJ, Leng RA, Hinch GN, Nolan J, Bindon BM, Piper LR. Effects of cottonseed supplementation on birthweights and survival of lambs from a range of litter sizes. Proc Aust Soc Anim Prod 1990, 18: 516.

[85] Kelly RW, Speijer EJ, Ralph IG, Newnham JP. Lambing performances and wool production in maiden adult Merino ewes fed different amount of lupin seed in midpregnancy. Aust J Agric Res 1992, 43: 339-354.

[86] Murphy PM, McNeill D, Fisher JS, Lindsay DR. Strategic feeding of Merino ewes in late pregnancy to increase colostrum production. Proc Aust Soc Anim Prod 1996, 21: 227-230.

[87] Banchero GE, Quinans G, Martin GB, Lindsay DR, Milton JTB. Nutrition and colostrum production in sheep. 1 . Metabolic and hormonal responses to high-energy supplement in the final stages of pregnancy. Reprod Fertil Dev 2004, 16: 633-643.

[88] O'Doherty JV, Crosby TF. The effect of diet in late pregnancy on progesterone concentration and colostrum yield in ewes. Theriogenology 1996, 46: 233-241.

[89] Dwyer CM, Lawrence AB, Bishop SC, Lewis M. Ewe-lamb bonding behaviours at birth are affected by maternal undernutrition in pregnancy. Brit J Nutr 2003, 89: 123-136.

[90] Shipka MP, Ford SP. Relationship of circulating oestrogen and progesterone concentrations during late pregnancy and the onset phase of maternal behaviour in the ewe. Appl Anim Behav Sci 1991, 31: 91-99.

[91] Thomson AM, Thomson W. Lambing in relation to the diet of the pregnant ewe. Brit J Nutr 1949, 2: 290-305.
[92] Whateley J, Kilgour R, Dalton DC. Behaviour of hill country sheep breeds during farming routines. Proc NZ Soc Anim Prod 1974, 34: 28-36.

[93] Le Neindre P, Murphy T, Boissy A, Purvis IW, Lindsay DR, Orgeur P, Bouix J, Bibé B. Genetics of maternal ability in cattle and sheep. 6th World Cong Gen Appl Livest Prod 1998, 27: 23-30.

[94] Alexander G, Stevens D, Bradley LR, Barwick SA. Maternal behaviour in BorderLeicester, Glen Vale (Border Leicester derived) and Merino sheep. Aust J Exp Agric 1990, 30: 27-38.

[95] Cloete SWP, Scholtz AJ. Lamb survival in relation to lambing and neonatal behaviour in medium wool Merino lines divergently selected for multiple rearing ability. Aust J Exp Agric 1998, 38: 801-811.

[96] Haughey KG. Perinatal lamb mortality - Its investigation, causes and control. Irish Vet J 1993, 46: 9-28.

[97] Haughey KG. The effect of birth injury to the foetal nervous system on the survival and feeding behaviour of lambs. In: Wodzicka-Tomasczewska M, Edey TN, Lynch JJ (Eds), Reviews in Rural Science, Vol 4, Armidale: University of New England, 1980, p 109-111.

[98] Dwyer CM. Behavioural development in the neonatal lamb: effect of maternal and birth-related factors. Theriogenology 2003, 59: 1027-1050.

[99] Knight TW, Lynch PR, Hall DRH, Hockey HUP. Identification of factors contributing to the improved lamb survival in Marshall Romney sheep. NZ J Agric Res 1988, 31: 259-271.

[100] O'Connor CE, Jay NP, Nicol AM, Beatson PR. Ewe maternal behaviour score and lamb survival. Proc NZ Soc Anim Prod 1985, 45: 159-162.

[101] Lambe NR, Conington J, Bishop SC, Waterhouse A, Simm G. A genetic analysis of maternal behaviour score in Scottish Blackface sheep. Anim Sci 2001, 72: 415425.

[102] Kilgour RJ, Szantar-Coddington MR. Arena behaviour of ewes selected for superior mothering ability differs from that of unselected ewes. Anim Reprod Sci 1995, 37: 133-142.

[103] Kuchel RC, Lindsay DR. Maternal behaviour and the survival of lambs in superfine wool sheep. Reprod Fertil Dev 2000, 11: 391-394. 
[104] Dwyer CM, Lawrence AB, Bishop SC. The effects of selection for lean tissue content on maternal and neonatal lamb behaviours in Scottish Blackface sheep. Anim Sci 2001, 72: 555-571.

[105] Cloete SWP, Scholtz AJ, Gilmour AR, Olivier JJ. Genetic and environmental effects on lambing and neonatal behaviour of Dormer and SA Mutton Merino lambs. Livest Prod Sci 2002, 78: 183-193.

[106] Atkins KD. The comparative productivity of five ewe breeds. 1. Lamb growth and survival. Aust J Exp Agric Anim Husb 1980, 20: 272-279.

[107] Kilgour R, De Langen H. Neonatal behaviour in "easy care" sheep. Rev Rural Sci 1980, 4: 117-118.

[108] Kelly RW. Lamb mortality and growth to weaning in commercial Merino flocks in Western Australia. Aust J Agric Res 1992, 43: 339-354.

[109] Banchero GE, Quinans G, Martin GB, Milton JTB, Lindsay DR. Nutrition and colostrum production in sheep. 2.
Metabolic and hormonal responses to different energy sources in the final stages of pregnancy. Reprod Fertil Dev 2004, 16: 645-653.

[110] Miller BV. Pregnacy and lambing. In: Cottle DJ (Ed), Australian Sheep and Wool Handbook, Melbourne, Inkata Press, 1991.

[111] Nowak R, Poindron P, Le Neindre P, Putu IG. Ability of 12-hour-old Merino and crossbred lambs to recognise their mothers. Appl Anim Behav Sci 1987, 17: 263-271.

[112] Shillito EE, Alexander G. Mutual recognition amongst ewes and lambs of four breeds of sheep (Ovis aries). Appl Anim Ethol 1975, 1: 151-165.

[113] Nowak R. Lamb's bleats: important for the establishment of the mother-young bond? Behaviour 1990, 115: 14-29.

[114] Nowak R, Poindron P, Sebe F, Hart KW, Chadwick A, Blache D. Divergent selection on temperament affect vocal and locomotor activity in isolated lambs. Proc Aust Soc Anim Prod 2006, (in press).

To access this journal online: www.edpsciences.org 